\title{
Chemical Composition and Physical Characteristics of Fruits of Two Cultivars of Blue Honeysuckle (Lonicera caerulea L.) in Relation to their Degree of Maturity and Harvest Date
}

\author{
Ireneusz OCHMIAN, Katarzyna SKUPIEŃ, Józef GRAJKOWSKI, \\ Miłosz SMOLIK, Krystyna OSTROWSKA \\ West Pomeranian University of Technology in Szczecin, Stowackiego 17, 71-434 Szczecin, Poland; ireneusz.ochmian@zut.edu.pl
}

\begin{abstract}
The aim of study was to compare yield, fruit quality, chemical composition and fruits colour of berries of two blue honeysuckle (Lonicera caerulea L.) cultivars of Polish bred 'Wojtek' and 'Brązowa' collected at the beginning and at the end of harvest season, respectively. On average, 'Wojtek' yielded $1565 \mathrm{~g}$ per bush, whereas 'Brązowa' $1941 \mathrm{~g}$. During the fruit ripening process, considerable changes were found in the fruit colour. Fruits of both cultivars became darker and their colour changed from green and yellow to red and blue. With the changes in fruit colour, considerable changes in firmness also occurred. Fruit ripening reduced fruit firmness and puncture resistance. For both genotypes, the berries of late harvest were bigger and richer in soluble solids and total polyphenol, however, they showed decreased firmness, lower acidity, and L-ascorbic acid content. Nevertheless the time of harvest, 'Wojtek' berries surpassed 'Brązowa' fruit regarding soluble solids, titratable acidity and L-ascorbic acid content (for late-crop berries of both cultivars 14.1 $>12.6 \%$, $3.4>2.7 \mathrm{~g}$ citric acid $100 \mathrm{~g}^{1}$, and 76>56 mg $100 \mathrm{~mL}^{-1}$. Further, 'Wojtek' berries showed higher total polyphenol content (149.30 and

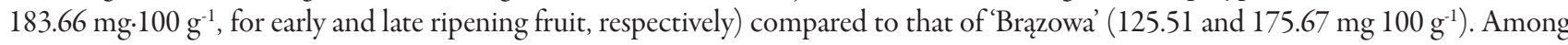
phenolics, anthocyanins made the substantial group ranging from $94.47 \mathrm{mg} 100 \mathrm{~g}^{-1}$ ('Brązowa' berries of early harvest) to $141.96 \mathrm{mg} 100$ $\mathrm{g}^{-1}$ (late 'Wojtek' fruit).
\end{abstract}

Keywords: chemical composition, cultivar, fruit colour, fruit size, Lonicera caerulea, phenolics

\section{Introduction}

According to different references, the genus Lonicera (Caprifoliaceae) comprises from 150 (Kumar et al., 2005) to more than 200 species (Naugžemys et al., 2007), which are native to Siberia, North Eastern Asia, and Japan. Some species in this genus are used as ornamental and edible plants. Berries have been long harvested from wild plants in regions of Russia, China, and Japan (Thompson and Chaovanalikit, 2006). However, in the scientific literature, the taxonomic classification of the species bearing edible fruits, especially of Lonicera caerulea, is not unequivocal (Chaovanalikit et al., 2004; Plekhanova, 2000). Lonicera caerulea, the blue honeysuckle, is also dubbed honeyberry, sweet berry honeysuckle, edible honeysuckle, haskap, haskup, hasukappu or haskappu. In the language of the Ainu people, the Aboriginal people of Hokkaidu Island, haskap means 'lots of little things on the top of the branches' (Bors, 2008a; Lefol, 2007). Blue honeysuckle plants have been used for ages in Asia for their medicinal properties. During the past several decades, research in Russia and Japan has resulted in cultivars being selected for commercial production (Thompson and Chaovanalikit, 2006,). Lately, breeding works have been also carried out in the Czech Republic (Rezniček, 2007), Belarus (Ru- pasova et al., 2007), Lithuania (Zhilinskayte et al., 2005), Canada (Lefol, 2007), USA (Thompson and Chaovanalikit, 2006), and in Poland (Ochmian et al., 2008; Smolik et al., 2010). In Japan, high prices make haskap products special for souvenirs and gifts for special occasions (Lefol, 2007). The great advantage of the blue honeysuckle is early ripening a few weeks before strawberries. The plants bear at a very young age and the fruit are easily shaken off at harvest time. They may be ideally suited for mechanized harvesting since they do not sucker and have bushes of a similar size to other fruits that are harvested by machines. The plants appear to have few insect pests and diseases, making it a worthwhile crop to be considered for organic production (Bors, 2008b). The plants are frost-resistant and the bushes are not damaged even when the temperature decreases beneath $-40^{\circ} \mathrm{C}$, whereas the expanded flowers are not injured at $-8^{\circ} \mathrm{C}$. The fruits are elongated with an elliptic or cylindrical shape that is covered with an abrading wax bloom. They have a flavour commonly described as a combination of blueberries and raspberries. The natural accessions and varieties provide a large range of taste, tartness, sweetness, and acidity (Lefol, 2007). Honeysuckle berries are used in a wide range of products including juice, wine, pastries, jams, dairy products and are eaten fresh. The fruits are rich in phenolics, anthocyanins and 
156

vitamin C (Chaovanalikit et al., 2004; Pigul, 2005; Rop et al., 2011). Consumption of high amounts of antioxidant substances may have a positive impact on human health, particularly the prevention of cancer and inflammatory diseases (Gazdík et al., 2008). Haskap berries are believed to have a variety of therapeutic effects as reducing blood pressure, decreasing the risk of heart attack, preventing osteoporosis and anaemia, preventing children hyperactivity, providing curative effects for malaria and gastrointestinal disorders, slowing the aging process (Lefol, 2007). The chemical composition of fruits determining their sensory attributes and pro-health properties is affected by environmental factors, harvest date, and genotype (Hoppula and Karhu, 2006; Poll and Petersen, 2003; Reyes-Carmona et al., 2005). The purpose of this study was to evaluate the effect of harvest date on the yield, fruit size and colour and firmness, as well as soluble solids, titratable acidity, $\mathrm{L}$-ascorbic acid, and phenol content for two honeysuckle cultivars of Polish bred, 'Wojtek' and 'Brązowa'.

\section{Material and methods}

The experiment was undertaken in the Experimental Station at Rajkowo (north-west Poland)-West Pomeranian University of Technology in Szczecin, in 2009-2010 years. The two-years old blue honeysuckle bushes were planted on 2005 in a brown podsolic soil rich in the nutrients, thus only nitrogen fertilisation was performed at the total dose of $40 \mathrm{~kg} \mathrm{~N}$ per ha. The plants were cultivated under conventional agronomic treatments adequate to low soil requirements of the species. The water irrigation was applied on 'as needed' basis during each vegetative season. Because Lonicera plants are resistant to pathogen diseases 'by nature' no chemical protection was applied. The ripe berries were collected consecutively. The fruit mass, firmness, colour, soluble solids, titratable acidity and L-ascorbic acid content were measured on fresh berries soon after each harvest. Phenolics composition was evaluated for berries collected at the beginning and the end of cropping season and the analyses were performed on fruits packed in polyethylene bags and stored at $-32^{\circ} \mathrm{C}$.

The fruit weight was measured with RADWAG WPX 4500 electronic scales ( $0.01 \mathrm{~g}$ accuracy) and fruit firmness was measured with a FirmTech 2 apparatus (BioWorks, USA). The firmness and puncture resistance of the skin of 100 randomly selected berries from each replicate was expressed as a gram-force causing fruit surface to bend 1 $\mathrm{mm}$. Puncture were made using a stamp with a diameter of $3 \mathrm{~mm}$.

Titratable acidity was determined by titration of a water extract of fruit juice with $0.1 \mathrm{~N} \mathrm{NaOH}$ to an end point of pH 8.1 (measured with an Orion $720 \mathrm{~A} \mathrm{pH}$ meter; Orion Research Incorporated, USA). Soluble solids content was determined with an Abbé refractometer. L-ascorbic acid and nitrates content was measured with a RQflex 10 reflectometer (Merck) and expressed as mg per $100 \mathrm{~mL}$ fruit juice.
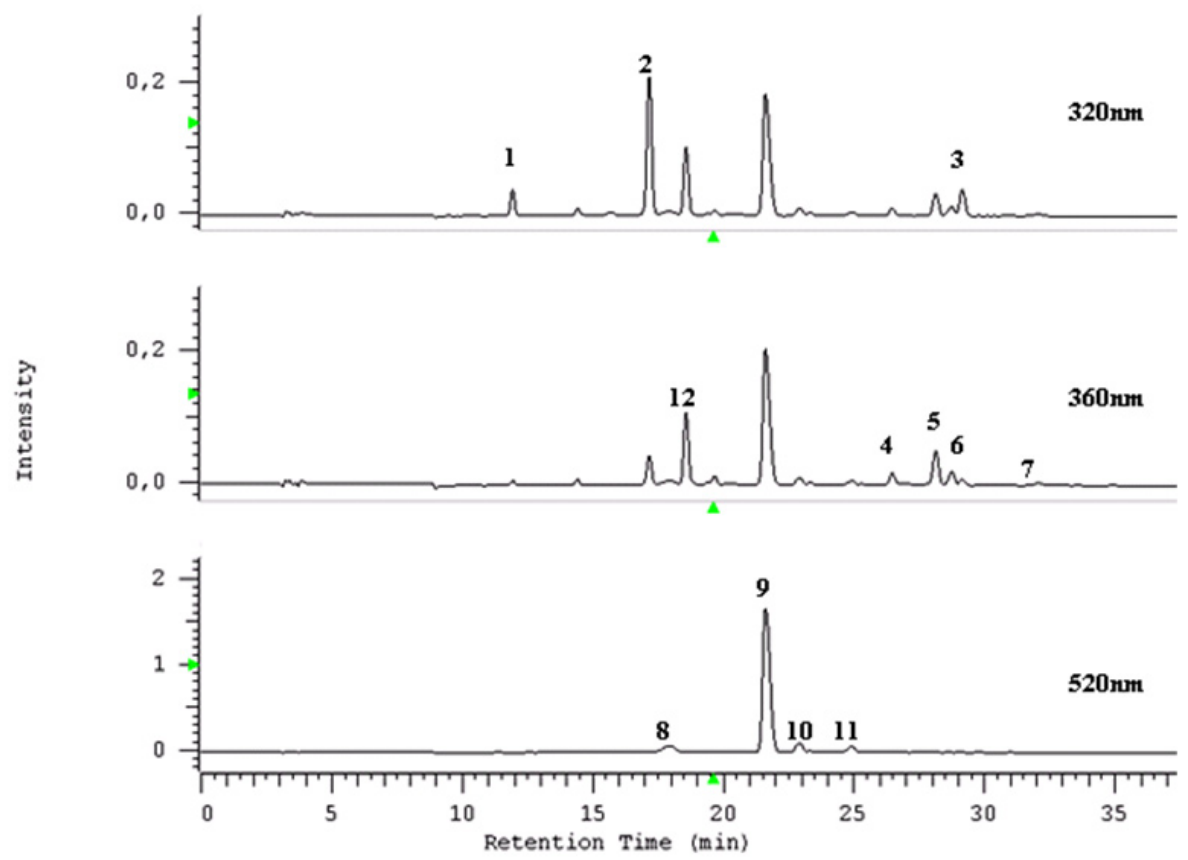

Fig. 1. Example of diagram of HPLC phenolics profile of blue honeysuckle fruit

1- neochlorogenic acid; 2- chlorogenic acid; 3- 3,5-dicaffeoylquinic acid; 4- unidentified flavonol (r. t. 26 min); 5- quercetin-3-rut; 6- quercetin-3-glu; 7- unidentified flavonol (r. t. 32 min); 8- cyanidin 3-5-diglu; 9- cyanidin-3-glu; 10 cyanidin-3-rut; 11 - peon-3-glu; 12 luteolin-7-O- $\alpha$-glu 
The HPLC analyses of polyphenols were carried out with HPLC apparatus consisting of a Merck-Hitachi L-7455 diode array detector (DAD) and quaternary pump L-119 7100 equipped with D-7000 HSM Multisolvent Delivery System (Merck-Hitachi, Tokyo, Japan). The runs were monitored for phenolic acids at $320 \mathrm{~nm}$, flavonols and luteolin glucoside at $360 \mathrm{~nm}$, and anthocyanin glycosides at $520 \mathrm{~nm}$ (Fig. 1). Retention times and spectra were compared to that of pure standards and total polyphenols content was expressed as $\mathrm{mg}$ per $100 \mathrm{~g}$ fruit tissue. Standards of anthocyanidin glycosides were obtained from Polyphenols Laboratories (Norway), while, for phenolic acids, flavonols and luteolin glucoside from Extrasynthese (France).

Fruit colour was measured in a transmitted mode through Konica Minolta CM-700d spectrophotometer. Measurements were conducted in CIE L'a "b" system (Fig. 2 ), through a $10^{\circ}$ observer type and D65 illuminant.
Chemical analyses were carried out in three replicates. The randomized block experimental design was used with three replicates (four bushes per a plot). The results obtained were subjected to statistical analysis using Statistica 9 (Statsoft, Poland). The results were evaluated by the Duncan test. The differences between the means at $p<0.05$ were considered significant.

\section{Results and discussion}

In each year of the experiment, fruits of both cultivars were harvested six or seven times (Fig. 3). 'Wojtek' berries started to ripen earlier than 'Brązowa' (on May 20) and the last harvest was carried out on June 10. 'Brązowa' berries were collected from June 1 to June 29 when air temperatures were higher (Tab. 1).

The yield of 'Wojtek' ranged from $97 \mathrm{~g}$ per bush (beginning of harvest) to $522 \mathrm{~g}$ per bush (the middle of harvest) and the total yield amounted $1565 \mathrm{~g}$ per bush on average.

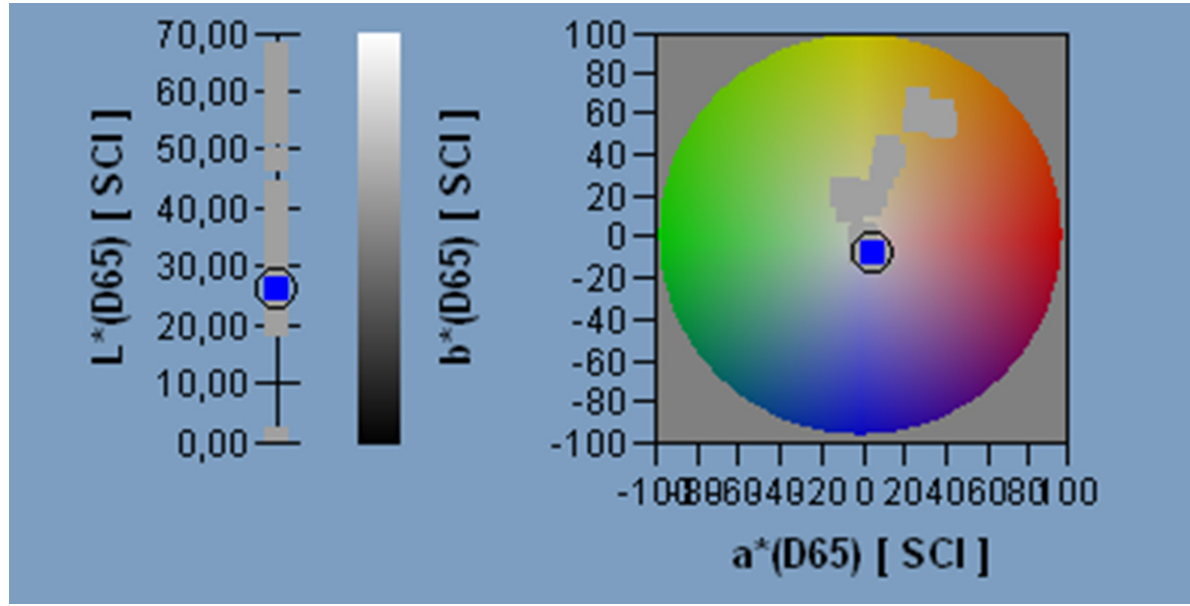

Fig. 2. CIE L*a*b* chromaticity diagram

$L^{*}$ (100 white, 0 black); a* (-100 green, +100 red); b* $(-100$ blue , +100 yellow $)$

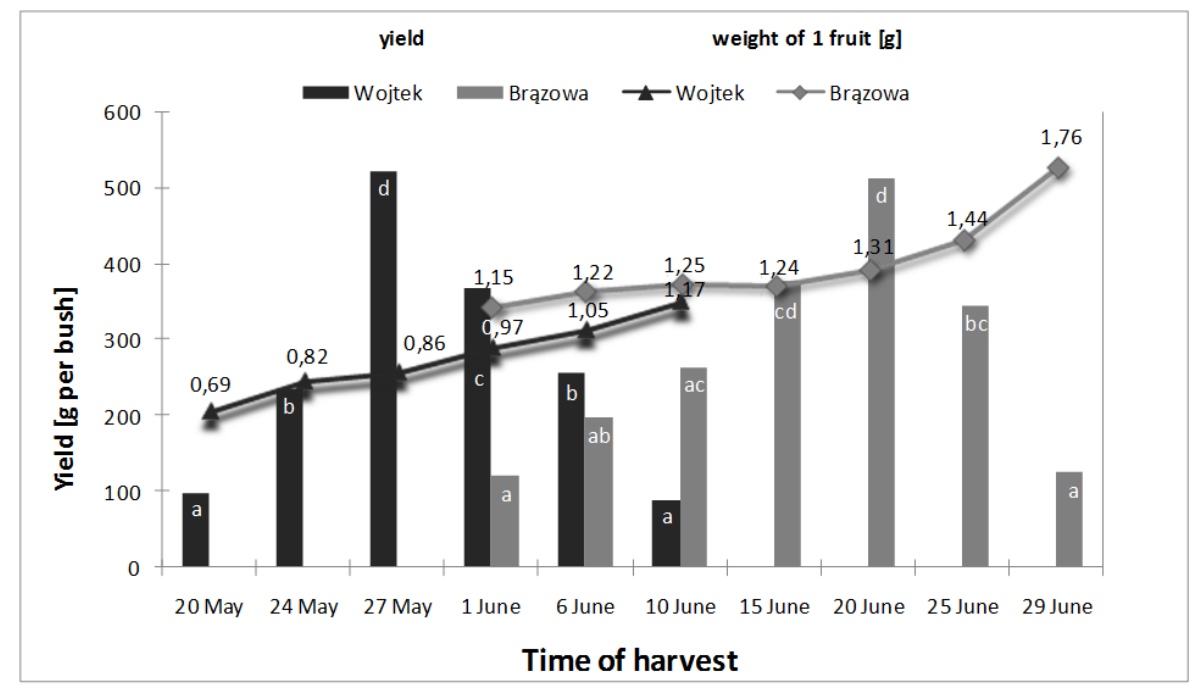

Fig. 3. Yield and one-fruit weight of blue honeysuckle at different harvest times (average for 2009-2010) 
158

Tab. 1. The mean air temperatures of April and June in 2009 and 2010

\begin{tabular}{|c|c|c|c|c|c|c|c|c|}
\hline & & \multicolumn{7}{|c|}{ Temperature $\left({ }^{\circ} \mathrm{C}\right)$} \\
\hline & Month & \multirow{2}{*}{ IV } & \multirow{2}{*}{ V } & \multirow{2}{*}{ VI } & & \multirow{2}{*}{ IV } & \multirow{2}{*}{ V } & \multirow{2}{*}{ VI } \\
\hline & 10 days & & & & & & & \\
\hline \multirow{3}{*}{$\begin{array}{c}\text { Year } \\
2009\end{array}$} & 1 & 7.2 & 11.8 & 18.9 & \multirow{3}{*}{$\begin{array}{c}\text { Year } \\
2010\end{array}$} & 7.9 & 12.2 & 15.7 \\
\hline & 2 & 11.5 & 13.8 & 19.4 & & 9.2 & 13.4 & 18.7 \\
\hline & 3 & 11.3 & 18.8 & 16.6 & & 10.5 & 15.3 & 18.2 \\
\hline
\end{tabular}

For 'Brązowa' the lowest yield per bush was $122 \mathrm{~g}$ (beginning of cropping), while the highest $512 \mathrm{~g}$ (the last but one harvest) totaling for $1941 \mathrm{~g}$ per bush (Fig. 3).

Bors (2008b) reported that the yield for 3-and 4-yearold honeysuckle seedlings was in the range of $0.5-0.75 \mathrm{~kg}$ per bush. Older plants can yield $1-5 \mathrm{~kg}$ per bush (Lefol, 2007; Ochmian and Grajkowski, 2007). The mass and size of berries play an important role in the evaluation of their quality and merits for customer attractiveness. One berry weight of some cultivars grown in Russia was reported as $0.5 \mathrm{~g}$, whereas Japanese cultivars can achieve $2.4 \mathrm{~g}$ (Arus and Kask, 2007). One-fruit weight of the Russian genotype honeysuckle, grown in Oregon (USA), is varied from 1 to $2 \mathrm{~g}$ (Hummer, 2006). The berries of different cultivars differed in their weight and dimensions in this research. On average, one-fruit weight of 'Brązowa' berries was higher (1.15-1.76 g) than 'Wojtek' (0.69-1.17 g). However, for both cultivars, a common trend was observed that berries of late harvests had higher one-fruit mass (Fig. 3) and bigger size (Tab. 2).

Late-cropped 'Wojtek' berries showed 41\% increase in diameter and 26\% increase in fruit length compared to fruit collected at the beginning of season, whereas, for

Tab. 2. Fruit size, firmness and puncture resistance of the skin of two blue honeysuckle cultivars

\begin{tabular}{|c|c|c|c|c|}
\hline \multirow{2}{*}{\multicolumn{2}{|c|}{ Characteristics }} & \multicolumn{2}{|c|}{ Cultivar } & \multirow[b]{2}{*}{ Mean } \\
\hline & & 'Wojtek' & 'Brązowa' & \\
\hline \multirow{2}{*}{$\begin{array}{c}\text { Fruit } \\
\text { diameter } \\
{[\mathrm{mm}]}\end{array}$} & $\begin{array}{c}\text { Harvest } \\
\text { beginning }\end{array}$ & $8.7 \pm 0.9 \mathrm{a} / \mathrm{A}^{\mathrm{a}}$ & $11.4 \pm 1 \mathrm{a} / \mathrm{B}$ & $10.0 \mathrm{a}$ \\
\hline & $\begin{array}{c}\text { End } \\
\text { of the harvest }\end{array}$ & $12.3 \pm 0.7 \mathrm{~b} / \mathrm{A}$ & $15.2 \pm 0.8 \mathrm{~b} / \mathrm{B}$ & $13.7 \mathrm{~b}$ \\
\hline \multirow{2}{*}{$\begin{array}{l}\text { Fruit } \\
\text { length } \\
{[\mathrm{mm}]}\end{array}$} & $\begin{array}{c}\text { Harvest } \\
\text { beginning }\end{array}$ & $18.7 \pm 0.8 \mathrm{a} / \mathrm{B}$ & $18.4 \pm 0.7 \mathrm{a} / \mathrm{A}$ & $18.5 \mathrm{a}$ \\
\hline & $\begin{array}{c}\text { End } \\
\text { of the harvest }\end{array}$ & $23.7 \pm 1.1 \mathrm{~b} / \mathrm{A}$ & $24.5 \pm 0.9 \mathrm{~b} / \mathrm{A}$ & $24.1 \mathrm{~b}$ \\
\hline \multirow{2}{*}{$\begin{array}{l}\text { Firmness } \\
{\left[\mathrm{G} \cdot \mathrm{mm}^{-1}\right]}\end{array}$} & $\begin{array}{c}\text { Harvest } \\
\text { beginning }\end{array}$ & $172 \pm 29 \mathrm{~b} / \mathrm{A}$ & $201 \pm 41 \mathrm{a} / \mathrm{B}$ & $186 \mathrm{~B}$ \\
\hline & $\begin{array}{c}\text { End } \\
\text { of the harvest }\end{array}$ & $148 \pm 15 \mathrm{a} / \mathrm{A}$ & $174 \pm 17 \mathrm{a} / \mathrm{B}$ & $161 \mathrm{~A}$ \\
\hline \multirow{2}{*}{$\begin{array}{c}\text { Puncture } \\
\text { (cracking) } \\
\text { the skin } \\
{\left[\mathrm{G} \cdot \mathrm{mm}^{-1}\right]}\end{array}$} & $\begin{array}{l}\text { Harvest } \\
\text { beginning }\end{array}$ & $78 \pm 15 \mathrm{a} / \mathrm{A}$ & $94 \pm 18 \mathrm{a} / \mathrm{B}$ & $86 \mathrm{~A}$ \\
\hline & $\begin{array}{c}\text { End } \\
\text { of the harvest }\end{array}$ & $62 \pm 12 \mathrm{a} / \mathrm{A}$ & $75 \pm 11 \mathrm{a} / \mathrm{A}$ & $68 \mathrm{~A}$ \\
\hline
\end{tabular}

${ }^{a}$ Different letters in the same row indicate significant differences at $p<0.05$. Lower case refer to harvest date (for particular cultivar), whereas, capital letters refer to comparisons of two genotypes
'Brązowa' berries, 33\% increases in diameter and length were found. The early ripening berries developed when air temperatures were lower (Tab. 1 and 2). Moreover, higher number of fruits per bush at the beginning of fruiting resulted in nutrient competition that could have contributed to the lowering of weight and size of early harvested honeysuckle berries. However, these data are contradictory to the findings of Ochmian et al. (2007) for strawberries and for highbush blueberries of Ścibisz et al. (2003) that berry size decreases through the harvest period. A reduction in irrigation might result in smaller fruits at harvest in open-field trials of strawberries (Kirnak et al., 2003) and apricot trees (Torrecillas et al., 2008). However, in this experiment, honeysuckle bushes were supplied with drip irrigation until the end of cropping that was suitable for fruit development.

The firmness of honeysuckle berries was influenced by the harvest date (Tab. 2 and 3). For both cultivars, the fruit of early harvest showed higher firmness than the ones collected late. Fruit size enlargement observed for latecrop 'Wojtek' and 'Brązowa' berries and it was concurrent with $14 \%$ decline in their firmness as compared to berries collected 25-30 days earlier. The decrease in fruit firmness during ripening is a common occurrence. According to Skupien et al. (2009), the early harvested fruit of other cultivars were harder if compared to the ones collected late. Nunes et al. (1995) found that firmness of strawberries cooled immediately after harvest was greater than those cooled after 6 hours, but the differences in firmness between harvests (beginning of harvest period and one week later, respectively) were not significant.

The damage of fruit skin is detrimental because it affects negatively the appearance that is especially important for fruits produced for fresh market purpose. However, no significant differences in the force needed to damage the fruits were found. They are quite low for the blue-berried honeysuckle, which means that fruits are susceptible to damage. No reports on this subject are available in the literature; however, results of the author's own experiments in this paper show that fruits of this species are relatively susceptible to puncture injury. Blackcurrant skin was damaged under the pressure of over $120 \mathrm{G} \mathrm{mm}^{-1}$, while some cultivars of northern highbush blueberry were damaged only at $140 \mathrm{G} \mathrm{mm}^{-1}$ (in press).

The physical parameters of fruits were significantly affected by the degree of fruit ripening (Tab. 3). Fruits from both cultivars under analysis darkened, which is confirmed by the change of the $\mathrm{L}^{*}$ parameter, which ranged from 59.99 to 56.12 in unripe fruits. The lowest value (21.08) was found in 'Wojtek' cultivar fruits just before harvest. The a parameter in unripe fruits had negative values $(-23.07 ;-21.43)$, which is a sign of the green color. Fruits became red in the ripening process, and the a parameter assumed a positive value. The greatest changes were observed for the $b$ parameter. Its values ranged from 39.87 ('Brązowa') to 42.83 ('Wojtek'), which reveals the 
presence of compounds that make the colour yellow. The values of the $b$ parameter were negative in unripe fruits and the fruits showed blue and red colours (Tab. 3).

Soluble solids (SS) were found between 9.6-12.6\% in this study and are in accordance with the findings of Kamzolova et al. (2006) for honeysuckle cultivars grown in Belarus. Nevertheless, at the time of harvest date, 'Wojtek' berries showed a higher amount of soluble solids than 'Brązowa' berries (Tab. 4). Additionally, it was found for both cultivars that berries collected early that ripen at lower temperatures have lower SS content than fruits of fruits harvested late (by 31-37\%). Similarly, Poll and Petersen (2003) observed low values of SS for sour cherries in the cold and rainy seasons. In general, honeysuckle berries are rich in organic acids. High amounts of acids impart a specific taste for blue honeysuckle berries resembling, for some people, bilberries with a distinct flavour of acidity. Total acid content (TA) varied from 2.7 to 4.4 g citric acid $100 \mathrm{~g} \mathrm{~g}^{-1}$ in this research (Tab. 4). Skupień et al. (2007) determined $2.98 \mathrm{~g}$ citric acid for 'Zielona' ber- ries, whereas Kamzolova et al. (2006) reported 1.79-3.24 g citric acid $100 \mathrm{~g}^{-1}$. For both genotypes evaluated in this study, berries of late harvest showed a lower acidity compared to the ones collected at an early stage. Also, Poll and Petersen (2003) observed a decrease of acidity for cherries picked at late season during harvest. The changes in SS and TA throughout cropping of both cultivars were reflected in an increase of SS:TA ratio for berries ripening late. The SS:TA of early harvested berries of 'Wojtek' was 2.3:1 and for ones harvested late, it was 4.1:1. The SS:TA for berries of 'Brązowa' was changed from 2.8:1 to 4.6:1 for late harvested fruits. Thus, late-collected honeysuckle berries of both cultivars had better sensory attributes. According to the results obtained, blue honeysuckle berries can be considered as a rich source of L-ascorbic acid (Tab. 4). The divergence observed between berries harvested early of 'Wojtek' and 'Brązowa' fruits harvested late ranged from 113 to $56 \mathrm{mg} 100 \mathrm{~mL}^{-1}$, respectively. Late-crop berries of both cultivars showed a significant decrease of $\mathrm{L}$-ascorbic acid content, changed from 27\% for 'Brązowa' and 33\%

Tab. 3. Color fruit, firmness and puncture resistance of the skin of two blue honeysuckle cultivars in dependence on harvest time

\begin{tabular}{|c|c|c|c|c|c|c|c|c|c|c|}
\hline \multirow{3}{*}{ Cultivar } & & \multicolumn{9}{|c|}{ Characteristics of fruits } \\
\hline & & \multicolumn{3}{|c|}{ Unripe fruits/green } & \multicolumn{3}{|c|}{ Beginning of fruit ripening } & \multicolumn{3}{|c|}{ Ripe fruits } \\
\hline & & $\mathrm{L}^{*}$ & $\mathrm{a}^{*}$ & $\mathrm{~b}^{*}$ & $\mathrm{~L}^{*}$ & $a^{*}$ & $b^{*}$ & $\mathrm{~L}^{*}$ & $a^{*}$ & $\mathrm{~b}^{*}$ \\
\hline \multirow{3}{*}{ 'Wojtek' } & CIE L*a*b* chromaticity & 59.88 & -23.07 & 42.83 & 41.15 & 2.67 & 19.77 & 21.08 & 1.43 & -25.40 \\
\hline & $\begin{array}{l}\text { Firmness } \\
{\left[\mathrm{G} \cdot \mathrm{mm}^{-1}\right]}\end{array}$ & \multicolumn{3}{|c|}{$423 \pm 34 c^{b}$} & \multicolumn{3}{|c|}{$278 \pm 52 \mathrm{~b}$} & \multicolumn{3}{|c|}{$161 \pm 25 \mathrm{a}$} \\
\hline & $\begin{array}{l}\text { Puncture (cracking) the skin } \\
{\left[\mathrm{G} \cdot \mathrm{mm}^{-1}\right]}\end{array}$ & \multicolumn{3}{|c|}{$335 \pm 18 \mathrm{c}$} & \multicolumn{3}{|c|}{$142 \pm 36 \mathrm{~b}$} & \multicolumn{3}{|c|}{$75 \pm 21 \mathrm{a}$} \\
\hline \multirow{3}{*}{ 'Brązowa' } & CIE L*a* ${ }^{*}{ }^{*}$ chromaticity & 56.12 & -21.43 & 39.87 & 39.18 & 9.94 & 17.35 & 25.73 & 4.27 & -22.49 \\
\hline & $\begin{array}{l}\text { Firmness } \\
{\left[\mathrm{G} \cdot \mathrm{mm}^{-1}\right]}\end{array}$ & \multicolumn{3}{|c|}{$449 \pm 40 \mathrm{c}$} & \multicolumn{3}{|c|}{$305 \pm 48 b$} & \multicolumn{3}{|c|}{$184 \pm 37 a$} \\
\hline & $\begin{array}{c}\text { Puncture (cracking) the skin } \\
{\left[\mathrm{G} \cdot \mathrm{mm}^{-1}\right]}\end{array}$ & \multicolumn{3}{|c|}{$311 \pm 23 \mathrm{c}$} & \multicolumn{3}{|c|}{$176 \pm 51 \mathrm{~b}$} & \multicolumn{3}{|c|}{$92 \pm 29 \mathrm{a}$} \\
\hline \multicolumn{2}{|r|}{ Sample color } & & & & & & & & & \\
\hline
\end{tabular}

${ }^{b}$ Different letters in the same row indicate significant differences at $p<0.05$

Tab. 4. The chemical composition in honeysuckle berries in dependence on harvest time fruit quality of two blue honeysuckle cultivars

\begin{tabular}{|c|c|c|c|c|}
\hline \multirow{2}{*}{\multicolumn{2}{|c|}{ Characteristics }} & \multicolumn{2}{|c|}{ Cultivar } & \multirow{3}{*}{$\frac{\text { Mean }}{9.9 \mathrm{~A}}$} \\
\hline & & \multirow{2}{*}{$\frac{\text { 'Wojtek' }}{10.3 \pm 0.3 \mathrm{a} / \mathrm{B}^{\mathrm{c}}}$} & \multirow{2}{*}{$\frac{\text { 'Brązowa' }}{9.6 \pm 0.2 \mathrm{a} / \mathrm{A}}$} & \\
\hline Soluble solids & Harvest beginning & & & \\
\hline$[\%]$ & End of the harvest & $14.1 \pm 0.3 \mathrm{~b} / \mathrm{B}$ & $12.6 \pm 0.2 \mathrm{~b} / \mathrm{A}$ & $13.3 \mathrm{~B}$ \\
\hline Titratable acidity & Harvest beginning & $4.4 \pm 0.3 \mathrm{~b} / \mathrm{B}$ & $3.4 \pm 0.2 \mathrm{a} / \mathrm{A}$ & $3.9 \mathrm{~B}$ \\
\hline$\left[\mathrm{g}\right.$ citric acid $\left.\cdot 100 \mathrm{~g}^{-1}\right]$ & End of the harvest & $3.4 \pm 0.3 \mathrm{~b} / \mathrm{A}$ & $2.7 \pm 0.3 \mathrm{a} / \mathrm{A}$ & $3.0 \mathrm{~A}$ \\
\hline L-ascorbic acid & Harvest beginning & $113 \pm 10 \mathrm{~b} / \mathrm{B}$ & $77 \pm 9 \mathrm{a} / \mathrm{A}$ & $95 \mathrm{~B}$ \\
\hline$\left[\mathrm{mg} \cdot 100 \mathrm{~mL}^{-1}\right]$ & End of the harvest & $76 \pm 6 \mathrm{~b} / \mathrm{A}$ & $56 \pm 6 \mathrm{a} / \mathrm{A}$ & $66 \mathrm{~A}$ \\
\hline Nitrates & Harvest beginning & $12.3 \pm 2.8 \mathrm{~b} / \mathrm{B}$ & $8.5 \pm 1.6 \mathrm{a} / \mathrm{B}$ & $10.4 \mathrm{~B}$ \\
\hline$\left[\mathrm{mg} \cdot 100 \mathrm{~mL}^{-1}\right]$ & End of the harvest & $7.2 \pm 2.1 \mathrm{a} / \mathrm{A}$ & $5.6 \pm 1.4 \mathrm{a} / \mathrm{A}$ & $6.4 \mathrm{~A}$ \\
\hline
\end{tabular}

cDifferent letters in the same row indicate significant differences at $p<0.05$. Lower case refer to harvest date (for particular cultivar), whereas, capital letters refer to comparisons of two genotypes 
Tab. 5. Fruit phenolic profiles of two honeysuckle cultivars in dependence on harvest time

\begin{tabular}{|c|c|c|c|c|}
\hline \multirow{3}{*}{$\begin{array}{l}\text { Phenolic compounds } \\
\mathrm{mg} \cdot 100 \mathrm{~g}^{-1}\end{array}$} & \multicolumn{2}{|c|}{ 'Brązowa' } & \multicolumn{2}{|c|}{ 'Wojtek' } \\
\hline & \multicolumn{4}{|c|}{ Time of harvest } \\
\hline & Harvest beginning & End of a harvest & Harvest beginnig & End of a harvest \\
\hline Neochlorogenic acid & $1.13 \mathrm{a}$ & $1.46 \mathrm{a}$ & $2.62 \mathrm{a}$ & $2.98 \mathrm{a}$ \\
\hline Chlorogenic acid & $14.63 \mathrm{a}$ & $19.58 \mathrm{~b}$ & $12.50 \mathrm{a}$ & $16.69 \mathrm{~b}$ \\
\hline 3,5- dicaffeoylquinic acid & $5.10 \mathrm{a}$ & $6.18 \mathrm{a}$ & $5.51 \mathrm{a}$ & $4.54 \mathrm{a}$ \\
\hline Sum of hydroxycinnamic acids & $20.86 \mathrm{a} / \mathrm{A}^{\mathrm{d}}$ & $27.22 \mathrm{~b} / \mathrm{A}$ & $20.62 \mathrm{a} / \mathrm{A}$ & $24.20 \mathrm{~b} / \mathrm{A}$ \\
\hline $\begin{array}{l}\text { Unidentified flavonol } \\
\text { (retention time } 26 \text { min) }\end{array}$ & $4.27 \mathrm{a}$ & $8.01 \mathrm{~b}$ & $1.08 \mathrm{~b}$ & $0.88 \mathrm{a}$ \\
\hline Quercetin 3-rutinoside & $2.96 \mathrm{a}$ & $6.36 \mathrm{~b}$ & $9.69 \mathrm{a}$ & $10.35 \mathrm{a}$ \\
\hline Quercetin 3-glucoside & $1.10 \mathrm{a}$ & $1.81 \mathrm{~b}$ & $2.68 \mathrm{a}$ & $5.17 \mathrm{~b}$ \\
\hline Unidentified flavonol (retention time $32 \mathrm{~min}$ ) & $1.85 \mathrm{a}$ & $3.00 \mathrm{~b}$ & $1.28 \mathrm{a}$ & $1.12 \mathrm{a}$ \\
\hline Sum of flavonols & $10.18 \mathrm{a} / \mathrm{A}$ & $19.18 \mathrm{~b} / \mathrm{A}$ & $14.73 \mathrm{a} / \mathrm{B}$ & $17.52 \mathrm{a} / \mathrm{A}$ \\
\hline Cyanidin 3-5-diglucoside & $8.08 \mathrm{a}$ & $7.09 \mathrm{a}$ & $4.17 \mathrm{a}$ & $6.70 \mathrm{~b}$ \\
\hline Cyanidin 3-glucoside & $81.71 \mathrm{a}$ & $115.71 \mathrm{~b}$ & $100.85 a$ & $123.51 \mathrm{~b}$ \\
\hline Cyanidin 3-rutinoside & $1.00 \mathrm{a}$ & $1.50 \mathrm{~b}$ & $5.96 \mathrm{a}$ & $7.56 \mathrm{~b}$ \\
\hline Peonidin 3-glucoside & $3.68 \mathrm{a}$ & $4.96 \mathrm{~b}$ & $2.98 \mathrm{a}$ & $4.18 \mathrm{~b}$ \\
\hline Sum of anthocyanins & $94.47 \mathrm{a} / \mathrm{A}$ & $129.25 \mathrm{~b} / \mathrm{A}$ & $113.95 \mathrm{a} / \mathrm{B}$ & $141.96 \mathrm{~b} / \mathrm{B}$ \\
\hline Luteolin 7-O- $\alpha$-glucoside & $4.60 \mathrm{a}$ & $5.52 \mathrm{a}$ & $5.08 \mathrm{a}$ & $7.86 \mathrm{~b}$ \\
\hline Total & $125.51 \mathrm{a} / \mathrm{A}$ & $175.67 \mathrm{~b} / \mathrm{A}$ & $149.30 \mathrm{a} / \mathrm{B}$ & $183.66 \mathrm{~b} / \mathrm{A}$ \\
\hline
\end{tabular}

${ }^{\mathrm{d}}$ Different letters in the same row indicate significant differences at $p<0.05$. Lower case refer to harvest date (for particular cultivar), whereas, capital letters refer to comparisons of two genotypes

for 'Wojtek' berries. In previous finding (Ochmian et al., 2009; Skupien et al., 2007), the average vitamin C content was $42 \mathrm{mg}$ ('Zielona') and $47 \mathrm{mg}$ in $100 \mathrm{~g}$ in 'Brązowa' berries. Kamzolova et al. (2006) reported a lower range of values varying from $28 \mathrm{mg}$ in $100 \mathrm{~g}$ ('Lubitelskaia') to $48 \mathrm{mg}$ in $100 \mathrm{~g}$ ('Berel'). The differences may result from genetic factors and environmental conditions in plant growth as well as disparate analytical methods applied.

The collected berries showed a range of 5.6 to $12.3 \mathrm{mg}$ of nitrates in $100 \mathrm{~mL}$. In Poland and other countries, there is a lack of regulations on the permissible nitrate content in fruits (except for bananas). According to the Polish Ministry of Agriculture (Dz. U., 2003), the permissible nitrate content in vegetables intended for feeding babies and young children should not exceed $200 \mathrm{mg} \mathrm{NaNO}$ $\mathrm{kg}^{-1}$. However, on the basis of previous surveys, ChemicalAgricultural Stations presume the admissible content in strawberries to be $250 \mathrm{mg} \mathrm{NaNO}$ per $\mathrm{kg}$ of fresh weight (Żurawicz, 2002). The levels of nitrates of honeysuckle fruits were comparable to those in vegetables like cucumber, parsley, broccoli and carrot, which accumulate up to $400 \mathrm{mg} \mathrm{NaNO} \mathrm{kg}^{-1}$.

The total phenol content for honeysuckles evaluated in this experiment was also cultivar- and harvest-date-dependent (Tab. 5). Early 'Wojtek' berries showed a lower content of phenolics (149.30 mg per $100 \mathrm{~g}$ ) compared to late-harvested berries (23\% increase). 'Brązowa' berries showed initially $125.51 \mathrm{mg}$ of total phenols per 100 $\mathrm{g}$, and then $40 \%$ enhancement occurred in late-ripening fruit. The total content of bioflavonoids (including compounds not identified in this research) in 51 honeysuckle genotypes tested in the Experimental Station in Pavlovsk and varied from 782 to $1890 \mathrm{mg}$ per $100 \mathrm{~g}$ (Strelcina $e t$ al., 2006). Among the phenolics identified for 'Wojtek' and 'Brązowa' berries, anthocyanins constituted a predominant group accounting for $73-82 \%$ of the total polyphenols (Tab. 5). Cyanidin-3-glucoside was the major anthocyanin determined in both cultivars with $83-90 \%$ participation in the total amount of anthocyanins. The minor pigments found in 'Brązowa' fruit in descending order were cyanidin-3,5-diglucoside followed by peonidin3-glucoside and cyanidin-3-rutinoside. 'Wojtek' showed a different decreasing order of minor anthocyanins: cyanidin-3-rutinoside $>$ cyanidin-3,5-diglucoside $>$ peonidin3-glucoside. Chaovanalikit et al. (2004) determined two additional anthocyanins, peonidin-3-rutinoside and pelargonidin-3-glucoside, in 10 genotypes of blue honeysuckle. In this experiment, berries collected late of both cultivars showed higher amounts of anthocyanins. Similarly, the stimulating effect of higher temperatures on anthocyanins accumulation in strawberries was observed by Wang and Zheng (2001). The authors found $782.7 \mathrm{ng} \mathrm{g}^{-1}$ anthocyanin content (as a sum of pelargonidin-3-glucoside and cyanidin-3-glucoside) for 'Earliglow' strawberries grown at day/night $30 / 22^{\circ} \mathrm{C}$ temperature cycle and $990.9 \mathrm{ng} \mathrm{g}^{-1}$ for 'Kent'. In contrast, at $18 / 12^{\circ} \mathrm{C}$, the total of anthocyanins in 'Earliglow' decreased to $309.8 \mathrm{ng} \mathrm{g}^{-1}$ and for 'Kent berries to $391.7 \mathrm{ng} \mathrm{g}^{-1}$. Poll and Petersen (2003) also observed lower anthocyanins levels in cherries picked during the season of low temperatures and lower solar radiation. Further, the decreasing order of three hydroxycinnamic acids identified for 'Wojtek' and 'Brązowa' was as follows: chlorogenic acid (68-80\% participation in total hydroxycinnamic acid) $>3,5$-dicaffeoylquinic acid (14-26\%), and 
neochlorogenic acid (3-10\%) (Tab. 5). Similarly to anthocyanins, berries collected late of both cultivars showed higher amounts of total hydroxycinnamic acids compared to early cropped fruits, mainly due to the enhancement of chlorogenic and a slight increase of neochlorogenic acid content, and despite of lowering 3,5-dicaffeoylquinic acid level (Tab. 5). The total of hydroxycinnamic acids displayed from 20.62 to $27.22 \mathrm{mg}$ per $100 \mathrm{~g}$ in this study and was lower than that obtained by Chaovanalikit $e t$ al. (2004). However, the content of hydroxycinnamic acids in 'Wojtek' and 'Brązowa' was similar to the level $(22.76 \mathrm{mg}$ per $100 \mathrm{~g}$ ) of 'Zielona' cultivar (Skupień et al., 2007).

Regarding total flavonols, early berries of both cultivars exhibited similar concentrations (Tab. 5). However, a significant increase of total flavonols was observed in late 'Brązowa' and 'Wojtek' berries throughout the harvest season. Quercetin 3-rutinoside was found as a predominant flavonol, especially for the 'Wojtek' berries. Moreover, quercetin 3-glucoside was also identified and two other derivatives eluting at 26 and 32 minutes were assigned as the unidentified flavonols. According to the data presented by Chaovanalikit et al. (2004) for 10 blue honeysuckle genotypes, the total flavonols per $100 \mathrm{~g}$ fresh weight ranged from 12.6 to 32.8 quercetin-3-rutinoside equivalents. Similar results were presented for 'Zielona' berries in our previous study (Skupień et al., 2007).

Luteolin-7-O- $\alpha$-glucoside was the only flavone identified in the evaluated cultivars. Like flavonols, berries collected early had similar amounts of luteolin-7-O- $\alpha$ glucoside and a significant increase was observed for both genotypes at the end of cropping season (Tab. 5). The overall range of luteolin-7-O- $\alpha$-glucoside content displayed from $4.60 \mathrm{mg}$ per $100 \mathrm{~g}$ (early 'Brązowa' berries) to 7.86 mg per $100 \mathrm{~g}$ ('Wojtek' fruit collected late) and was lower than $9.40 \mathrm{mg}$ per $100 \mathrm{~g}$ reported previously for 'Zielona' berries (Skupień et al., 2007). Strelcina et al. (2006) determined a wide divergence in luteolin glycoside content (1.5-20.7 mg per $100 \mathrm{~g}$ ) for genotypes estimated in Russia. In this research, 'Wojtek' berries exhibited significant increase $(54 \%)$ in luteolin-7-O- $\alpha$-glucoside content, while 'Brązowa' displayed only $19 \%$ increasing at the end of harvest season. The participation of luteolin 7-O- $\alpha$-glcoside in total phenols ranging from $3.1 \%$ for 'Brązowa' berries harvested late to $4.3 \%$ for 'Wojtek' fruit cropped late.

\section{Conclusions}

Blue honeysuckle is a plant with fruits that ripen very early. Under the climactic conditions of north-western Poland, the first berries of the Wojtek cultivar are picked in mid-May and the Brązowa cultivar berries can be picked from the beginning of June. Fruits ripen in a gradual manner and they are harvested several times. The Brazowa cultivar produces a higher yield-up to $2 \mathrm{~kg}$ of fruit can be collected from one bush. The fruits are larger, firmer, have a higher puncture resistance and contain more poly- phenolic compounds. Fruits from the Wojtek cultivar, on the other hand, are characterized by a higher content of the extract, organic acid and vitamin C. Blue honeysuckle berries are also a rich source of polyphenolic compoundsanthocyanins make up approx. $75 \%$ of the polyphenolics, depending on the cultivar and harvest time.

During the fruit-ripening process, considerable changes were found in the fruit colour. Fruits of both cultivars became darker and their colour changed from green and yellow to red and blue. With the changes in fruit colour, considerable changes in firmness also occurred. Fruit firmness and puncture resistance were reduced with fruit ripening. During the vegetative period, changes in the size and quality of the berries were observed. Berries from both cultivars were significantly larger during the last harvest than at the beginning of the harvest time. Larger lateharvest berries were less puncture-resistant, however, they were characterized by a considerably higher content of SS and polyphenolic compounds and a lower content of TA and vitamin C. In practical terms, because of the fruit size and higher firmness, 'Brązowa' berries seem to be more consumer-attractive and better suited for handling operations. However, regarding the amount of nutritional and biologically active compounds, both cultivars are valuable, especially berries of late harvest.

\section{Acknowledgements}

This work was supported by the Polish Ministry of Science and Higher Education under grant No. N N310 205737

\section{References}

Arus L, Kask K (2007). Edible honeysuckle (Lonicera caerulea var. edulis)-underutilized berry crop in Estonia. NJF Report $3(1): 33-35$.

Bors B (2008a). Blue honeysuckle [online]. Access 23 July 2008. Available: http://www.usask.ca/agriculture/plantsci/dom_ fruit/articles/blue_honeysuckle2.pdf.

Bors B (2008b). Haskap breeding at the University of Saskatchewan [online]. Access 23 July 2008. Available: http://www.usask.ca/agriculture/plantsci/dom_fruit/ articles/organic.pdf. [2011 July 23].

Chaovanalikit A, Thompson MM, Wrolstad RE (2004). Characterization and quantification of anthocyanins and polyphenolics in blue honeysuckle (Lonicera caerulea L.). J Agric Food Chem 52:848-852.

Gazdík Z, Krška B, Adam V, Šaloun J, Pokorná T, Řezníček V, Horna A, Kizek R (2008). Electrochemical determination of the antioxidant potential of some less common fruit species. Sensors 8:7564-7570.

Hoppula KB, Karhu ST (2006). Strawberry fruit quality responses to the production environment. J Food Agric Environ 4(1):166-170.

Hummer KE (2006). Blue honeysuckle: a new crop for North 
162

America. J Am Pomol Soc 60(1):3-8.

Kamzolova OI, Pigul ML, Lipskaia SL (2006). Biochimicheskaja ocenka sortov zhimolosti siniei $\mathrm{v}$ usloviach Belarussii. Plodovodstvo 18(1):110-114.

Kirnak H, Kaya C, Higgs D, Bolat I, Simsek M, Ikinci A. (2003). Effects of preharvest drip-irrigation scheduling on strawberry yield, quality and growth. Austr J Exp Agric 43(1):105-111.

Kumar N, Singh B, Bhandari P, Gupta AP, Uniyaj SK, Kaul VK (2005). Bioflavonoid from Lonicera japonica. Phytochem 66:2740-2744.

Lefol EB (2007). Haskap Market Development-The Japanese Opportunity-Feasibility Study.

Naugžemys D, Žilinskaitė S, Denkovskij J, Patamsytė J, Literskis J, Žvingila D (2007). RAPD based study of genetic variation and relationships among Lonicera germplasm accessions. Biologija 53:34-39.

Nunes MCM, Brecht JK, Morais AMMB, Sargent SA (1995). Physical and chemical quality characteristics of strawberries after storage are reduced by a short delay to cooling. Postharv Biol Technol 6:17-28.

Ochmian I, Grajkowski J (2007). Growth and yielding of blue honeysuckle (Lonicera caerulea) three cultivars in Western Pomerania in first years after planting. Rocz AR Pozn CCCLXXXIII. Ogrodn 41:351-355

Ochmian I, Grajkowski J, Kirchhof R (2007). Wpływ mulczowania gleby na plonowanie oraz jakość owoców truskawki odmiany 'Filon'. Rocz AR w Poznaniu, Ogrodnictwo 383(41):357-362.

Ochmian I, Grajkowski J, Skupień K (2008). Field performance, fruit chemical composition and firmness under cold storage and simulated "shelf-life" conditions of three blue honeysuckle cultigens (Lonicera caerulea). J Fruit Ornam Plant Res 16:83-91.

Ochmian I, Oszmiański J, Skupień K (2009). Chemical composition, phenolics, and firmness of small black fruits. J Appl Bot Food Qual 83: 64-69.

Pigul ML (2005). Zimostojkost' i khimičeskij sostov plodov žimolosti. Plodovodstvo 17(1):239-242.

Plekhanova MN (2000). Blue honeysuckle (Lonicera caerulea L.)-a new commercial berry crop for temperate climate: genetic resources and breeding. Acta Hort 538:159-164.

Poll L, Petersen MB (2003). Influence of harvest year and harvest time on soluble solids, titratable acid, anthocyanin content and aroma components in sour cherry (Prunus cerasus L. cv. 'Stevnsbær'). Eur Food Res Tech 216:212-216.

Reyes-Carmona J, Yousef GG, Martínez-Peniche Lila MA (2005). Antioxidant capacity of fruit extracts of blackberry (Rubus sp.) produced in different climatic regions. J Food Sci. 70(7): 497-503.

Řezniček V (2007). Evaluation of the variability of a selected group of varieties of honeysuckle-Lonicera caerulea subsp. Turcz. ex Freyn. International Conference Vaccinium spp. and less known small fruits-cultivation and health benefit and COST 863. Euroberry Research, September 30-October 5, IPGB Nitra, Slovak Republic.

Rop O, Řezníček V, Mlček J, Juríková T, Balík J, Sochor J, Kramářová D (2011). Antioxidant and radical oxygen species scavenging activities of 12 cultivars of blue honeysuckle fruit. Hort Sci 38(2): 63-70.

Rupasova ŽA, IgnatenkoVA, Varavina NP, Garanovič IM, Špitalnaja TV (2007). Sortovyje osobennosti biokhimicheskogo sostava plodov zhimolosti cjedobnoj Lonicera edulis Turcz. Ex Freyn. (na primiere kollekciji CBS NAN Belarusi).

Ścibisz I, Mitek M, Malewska J (2003). Aktywność przeciwutleniająca owoców borówki wysokiej. Żywność Suppl 2(35):159-166.

Skupień K, Oszmiański J, Ochmian I, Grajkowski J (2009). Influence of ripening time on fruit chemcal composition of two blue honeysuckle cultigens. J Fruit Ornam Plant Res 17(1):101-111

Skupień K, Oszmiański J, Ochmian I, Grajkowski J (2007). Characterization of selected physico-chemical features of blue honeysuckle fruit cultivar 'Zielona'. Polish J Nat SciSuppl 4:101-107.

Smolik M, Ochmian I, GrajkowskiJ (2010). Genetic variability of Polish and Russian accessions of cultivated blue honeysuckle (Lonicera caerulea). Russ J Genet 46(8):1079-1085.

Strelcina SA, Sorokin AA, Plekhanova MN, Lobanova EV (2006). Sostav biologičeski aktivnyh fenolnyh soiedinienii sortov zhimolosti $\mathrm{v}$ usloviah severno-zapadnoi zony plodovodstva RF. Agrarnaia Rossia 6:67-72.

Thompson MM, Chaovanalikit A (2006). Preliminary observations on adaptation and nutraceutical values of blue honeysuckle (Lonicera caerulea) in Oregon, USA. Acta Hort 626:65-72.

Torrecillas A, Domingo R, Galego R, Ruiz-Sánchez MC (2008). Apricot tree response to withholding irrigation at different phonological periods. Sci Hort 85(3):201-215.

USDA, ARS, National Genetic Resources Program (2008). Germplasm Resources Information Network-(GRIN) [Online Database]. National Germplasm Resources Laboratory, Beltsville, Maryland. Access 23 July 2008. Available: www.ars-grin.gov/cgi- in/npgs/html/taxon. pl?405434.

Wang SY, Zheng W (2001). Effect of plant growth temperature on antioxidant capacity in strawberry. J Agric Food Chem 49:4977-4982.

Zhilinskayte S, Radaitene D, Auchina A (2005). Ocenka kollekciji geneticheskikh resursov zhimolosti v Botanicheskom Sadu Vilniusskogo Universiteta. Plodovodstvo $17(2): 351-354$

Żurawicz E (2002). Proekologiczne technologie produkcji owoców. Integrowana produkcja owoców truskawki. Skierniewice, $64 \mathrm{p}$. 